جداسازى زنهاى لينالول سنتاز و يينن سنتاز از گياه دارويى بومادران (Achillea millefolium L.)

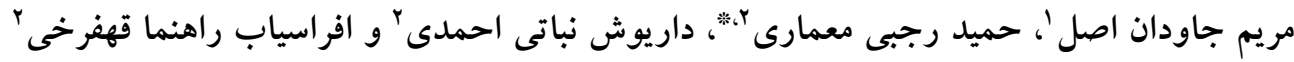

$$
\begin{aligned}
& \text { 1- دانش آموخته كارشناسى ارشد، كروه زراعت و اصلاحنباتات، دانشكده كثاورزى، دانشخاه شهيد خجمران، اهواز }
\end{aligned}
$$

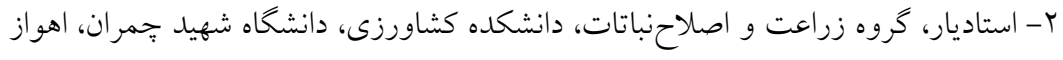

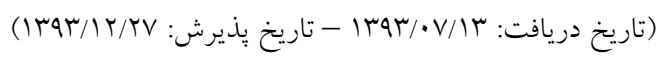

جكيده

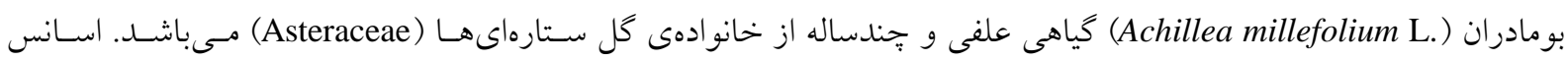

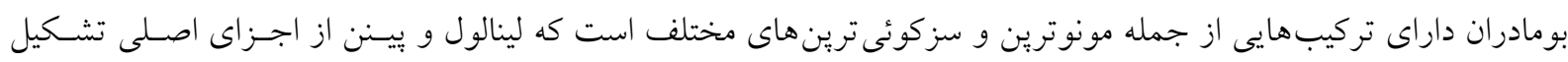

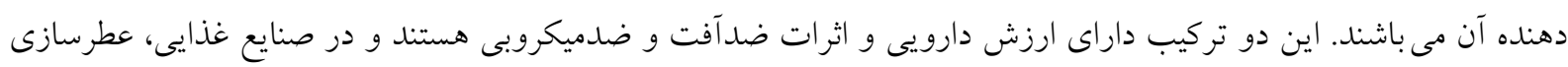

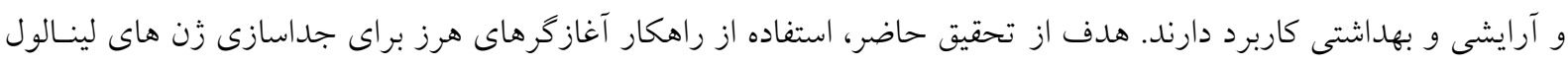

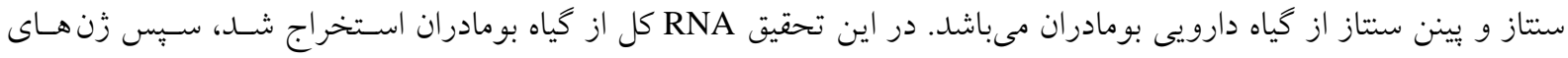

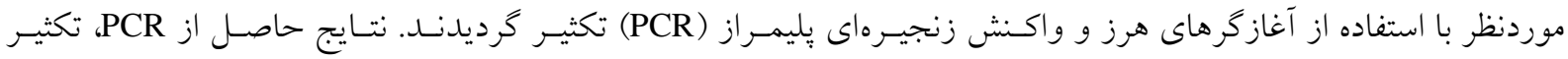

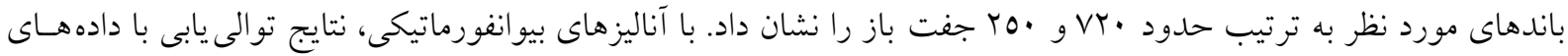

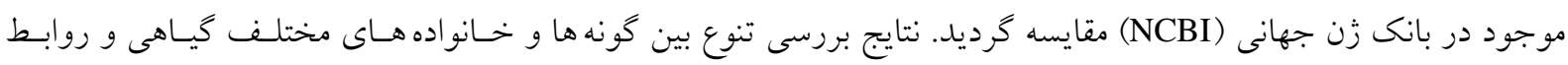

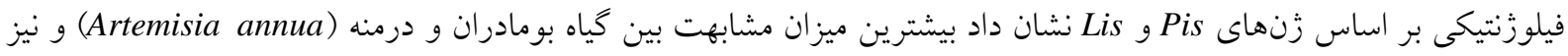

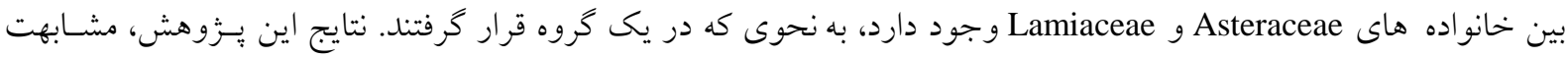

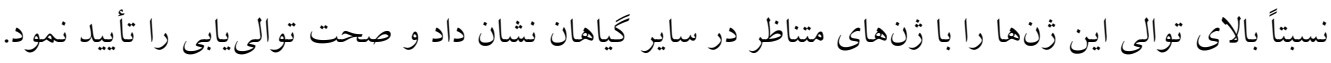
وازگان كليدى: آغازگر هرز، بومادران، بينن سنتاز، ترينها، لينالول ستتاز 


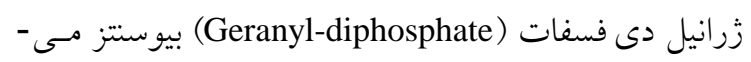

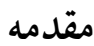

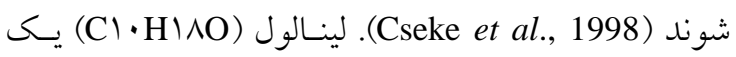

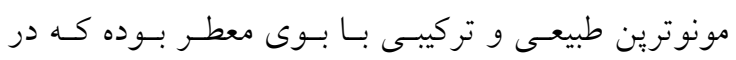

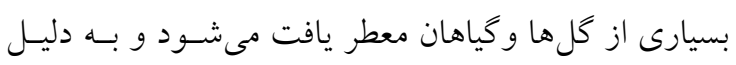

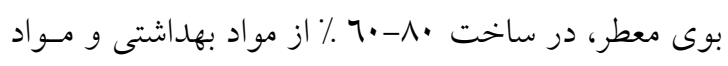

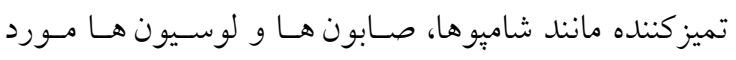

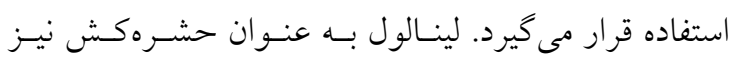

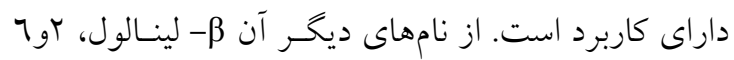

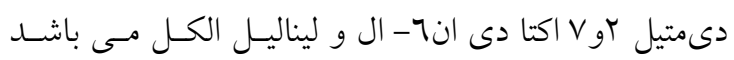

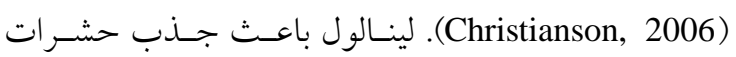

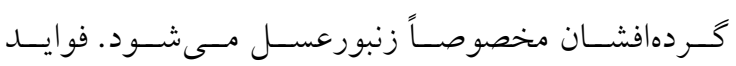
آرومـاترايى آن عبـارت از ايجـاد روحيـه شــاد در انسـان

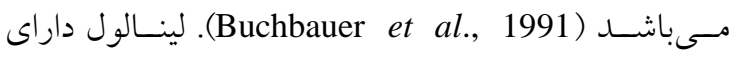
خاصسيت ضــتومورى اسـت (Loizzo et al., 2007) و همجنين به عنوان يك حدواسط مهم در توليد ويتامين A و E نيز استفاده مى شود (Mercier et al., 1994). لينالول كه A. ) از تركيبات روغن اساسى بيشتر زيركونههاى بومادران

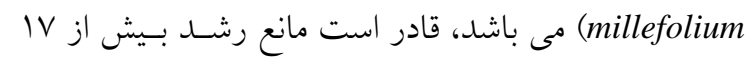
نوع باكترى و ·ل نوع قارج شود (Pattnaik et al., 1997).

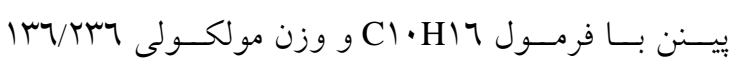

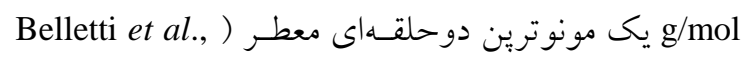

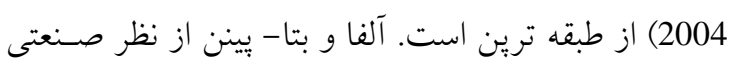
بسـيار مهــم بــوده و در سـاخت انسواع معطر كنــــهـــا،

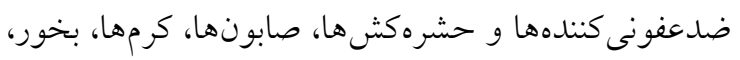

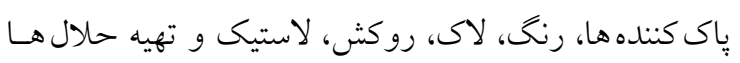

بهار مىروند (Chalchat et al., 2001).

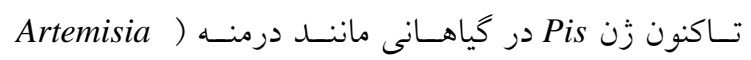
كاز خانو اده (annua

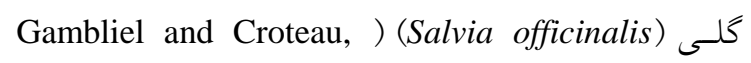
1982)، نتخـود (Cicer arietinum et al., ) (Cichay

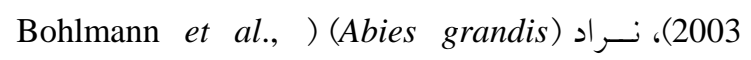
1997)، كوجـــه وحشــ (Solanum habrochaites) و زن لينـالول سـتناز در (Gonzales-Vigil et al., 2012)

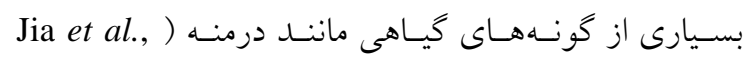


كرديدند. مقايسه و همرديفى توالىهاى يروتئينى و نوكلئوتيدى متناظر با هريك از زنهاى موردنظر در

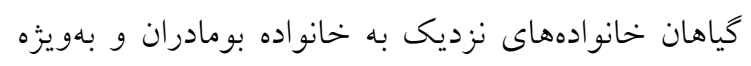

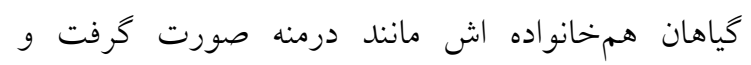
براساس نواحى حفاظتشده، يكى جفت آغازگر هرز مستقيم و معكوس براى هر يك از (Degenerate primer) زنهاى Pis و بis براى تكثير قطعهاى مورد نظر از زنوم كياه بومادران طراحى كرديد (جدول (1). ساخت آغاز خرها توسط شركت Bioneer كره جنوبى صورت گرفت. استخراجRNA كل: استخراج RNA از نمونههاى برگ و كل با استفاده از دستورالعمل Rneasy Plant Mini kit بر اساس روش ارائه شده توسط شركت (Qiagen)

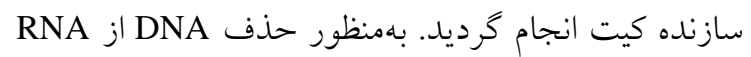
استخراج شده، از آنزيم DNase شركت Fermentas آلمان استفاده شد. در نهايت لولهى حاوى RNA براى استفاده طولانى مدت به فريزر Co م- •م- منتقل كرديد. كيفيت و كميت RNA استخراجى با بارگذارى بر روى زل آَّارز

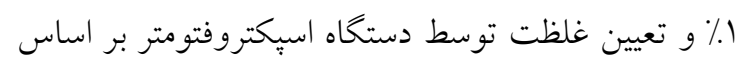

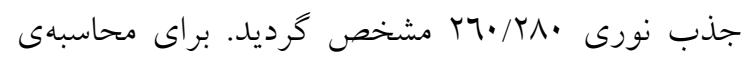
غلظت RNA استخراجشده از فرمول زير استفاده شد (X) = غلظت RNA تكى رشتهاى در نمونه). $\mathrm{Xng} / \mu \mathrm{l}=\mathrm{OD}_{\text {rฯ. }} \times 0$.
1999)، ريحــان (Ocimimam basilicum et al., ) (Ocimum 2004)، سيب (Malus domestica) (al., 2013 و آرابيدويسـيس (Arabidopsis thaliana) جداسازى و توالى يـابى كرديـده (Aubourg et al., 2002) است. هم:جنين از كياهان خانواده Asteraceae جداسـازى ساير زنهاى مسيرهاى دارويى ماننــ زن زِارتنوليـد سـنتاز Tanacetum از بابونــه كبيـر (Parthenolide synthase) Germacrene A ،(Liu et al., 2014)(parthenium (Cichorium intybus) synthase Kim ) Ixeris dentata gouwmeester et al., 2002) Amorpha-4,11-diene synthase و زن (et al., 2005 كـــارش (Chang et al.,2000) از كيــاه درمنـــ (ADS)

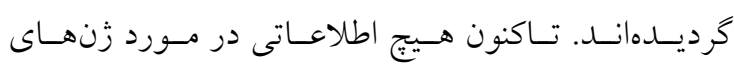

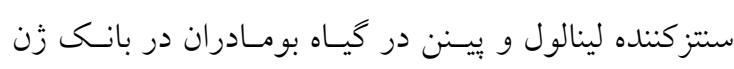
جهانى وجود ندارد. يزوهش حاضر، بهمنظور جداسـازى زنهاى Lis و Pis با طراحى برايمرهـاى مناسـب، از كيـاه بومادران هزاربرى صورت كرفت. مواد و روشها نمونهاى گل و برى بومادران مورد استفاده در اين تحقيق از باغ گياهشناسى دانشكده داروسازى دانشخاه علوم يزشكى جندى شايور در مرحله كلدهى جمع آورى كرديدند. نمونهها يس از برداشت، با نيتروزن مايع (دماى

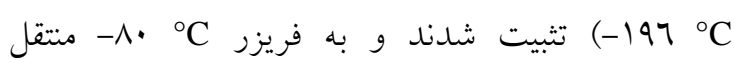

Mega 5 جدول ا- توالى هاى آغاز گرهاى مستقيم و معكوس طراحى شده به كمك نرم افزار

Table 1. The sequences of forward and backward primers desined by Mega5

\begin{tabular}{|c|c|c|c|}
\hline زن & آغازگر & 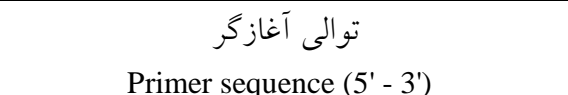 & توالى هرز \\
\hline Pis & F-PIN & GAGTTTGCSAAACTSGACTTCAA & $\mathrm{S}[\mathrm{C} / \mathrm{G}]$ \\
\hline Pis & R-PIN & GTACCATACACATCRTAAACATCRTC & $\mathrm{R}[\mathrm{A} / \mathrm{G}]$ \\
\hline Lis & F-LIN & ACTCTCGATGATGTYTAYGA & $\mathrm{Y}[\mathrm{C} / \mathrm{T}]$ \\
\hline Lis & R-LIN & GTATCACCTCTYTCCATYTC & $\mathrm{Y}[\mathrm{C} / \mathrm{T}]$ \\
\hline
\end{tabular}


تكثير زن بينن سنتاز به روش واكنش زنجيرهاى بليمراز:

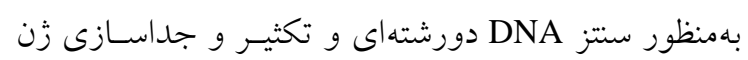

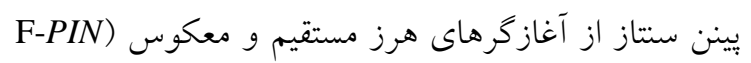

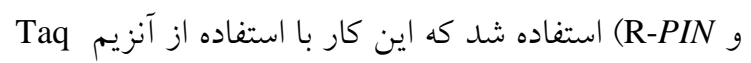

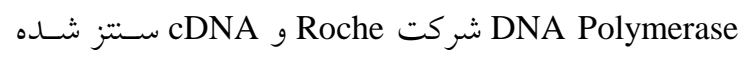

از RNA استخراج شده از گل بومـادران (بـهدليـل داشـن

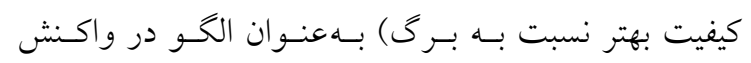

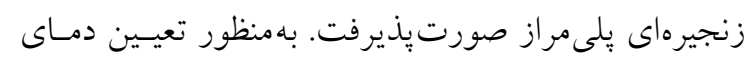

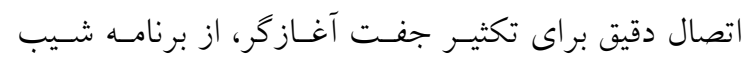

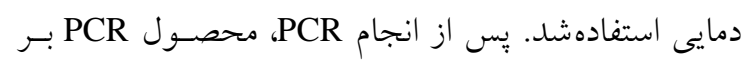

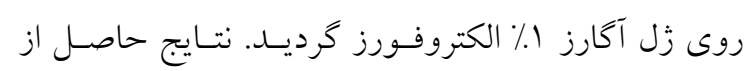

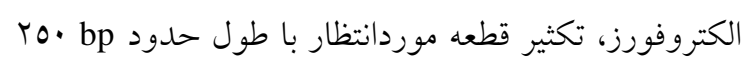

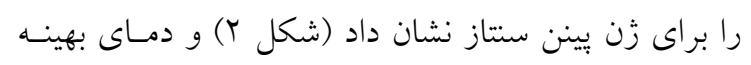
براى اتصال، جهت تكثير اين زن بهوسيله آغازگرهاى هرز

$$
\text { طراحى شده، }
$$

بررسى نتايج حاصل از توالى يابى زن يِنن سنتاز: نتسايج

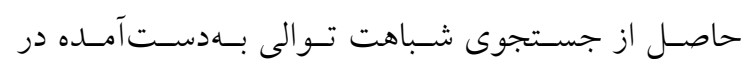

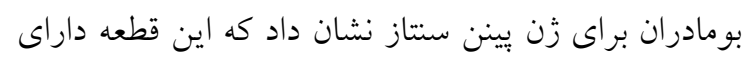

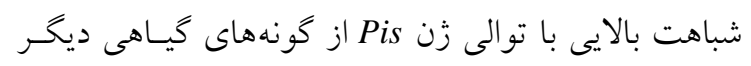

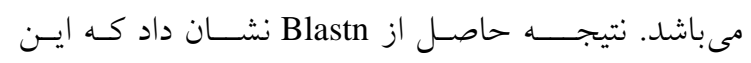

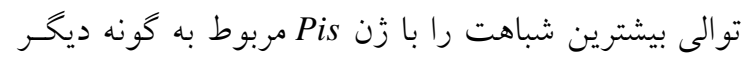
(Asteraceae)

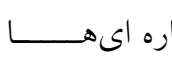

سنتز رشته اول CDNA: براى تبديل RNA به في

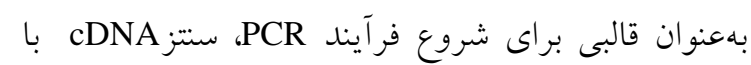

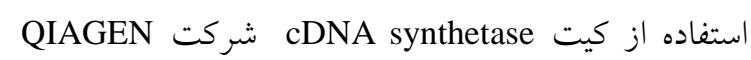

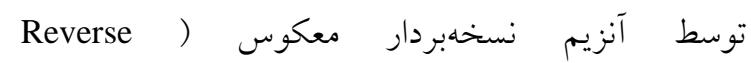
Omniscript (Transcriptase

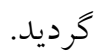

تكثير زن بينن سنتاز و لينالول سنتاز به روش PCR: به

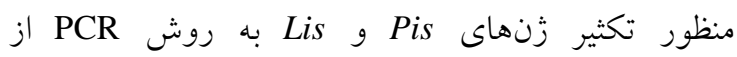

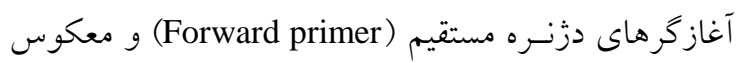

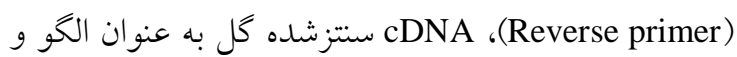
آنزيم Taq DNA Polymerase شركت Roche و Riolabs استفاده گرديد (جدول Y). جهت تعيين دماى اتصال دقيق براى تكثير جفت آغازگر، از برنامه شيب دمايى استفاده شد. سبس، محصول PCR جهت تعيين توالى به شركت Bioneer

\section{نتايج و بحث} اســتخراج RNA: ارزيــابى كيفيــت و كميــت RNA

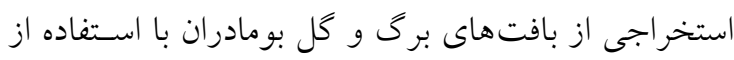

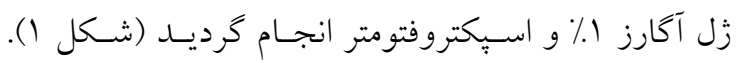

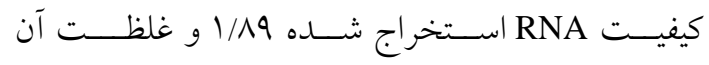

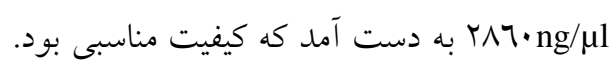

$$
\text { جدول r- اجزاى واكنش PCR براى زنهاى Pis و Pis }
$$

\begin{tabular}{|c|c|c|c|c|}
\hline \multicolumn{2}{|c|}{$\begin{array}{l}\text { حجم (ميكروليتر) } \\
\text { Volume ( } 1 \text { (م1) }\end{array}$} & \multicolumn{2}{|c|}{ 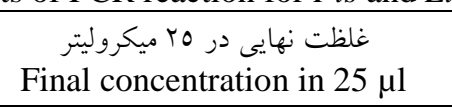 } & \multirow{2}{*}{$\begin{array}{l}\text { مواد } \\
\text { Materials }\end{array}$} \\
\hline Lis & Pis & Lis & Pis & \\
\hline 4.00 & 2.00 & 200 ng & $200 \mathrm{ng}$ & $\begin{array}{c}\text { الكَ cDNA } \\
\text { Template cDNA }\end{array}$ \\
\hline 0.50 & 0.50 & $0.20 \mathrm{mM}$ & $0.20 \mathrm{mM}$ & $(10 \mathrm{mM}) \mathrm{dNTPs}$ \\
\hline 1.25 & 1.00 & $0.50 \mu \mathrm{M}$ & $0.40 \mu \mathrm{M}$ & 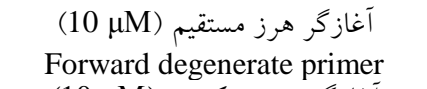 \\
\hline 1.25 & 1.00 & $0.50 \mu \mathrm{M}$ & $0.40 \mu \mathrm{M}$ & $\begin{array}{l}\text { آغازكر هرز معكوس (10 } 10 \mathrm{MM}) \\
\text { Reverse degenerate primer }\end{array}$ \\
\hline 0.25 & 0.15 & $0.02 \mathrm{U}$ & $1.25 \mathrm{U}$ & Taq DNA Polymerase \\
\hline 5.00 & 2.50 & $(2.00 \mathrm{mM}) 1 \mathrm{X}$ & $(1.5 \mathrm{mM}) 1 \mathrm{X}$ & (Containing MgCl2) PCR buffer \\
\hline 12.75 & 17.85 & Up to $25 \mu 1$ & Up to $25 \mu 1$ & $\begin{array}{c}\text { آب مقطر ديونيزه استريل } \\
\text { Sterile deionized distilled water }\end{array}$ \\
\hline
\end{tabular}

Table 2. The components of PCR reaction for Pis and Lis genes 


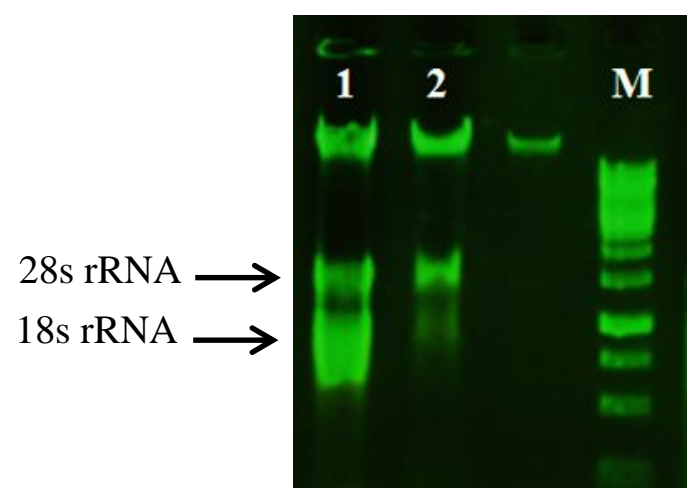

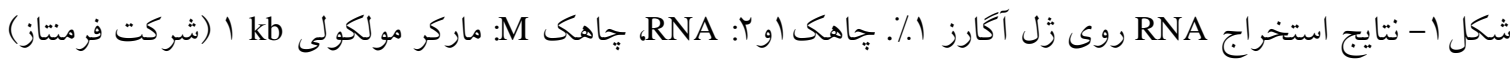

Figure 1. Results of RNA extraction on 1\% agarose gel. 1 and 2: RNA, M: 1Kb Marker (Fermentas)

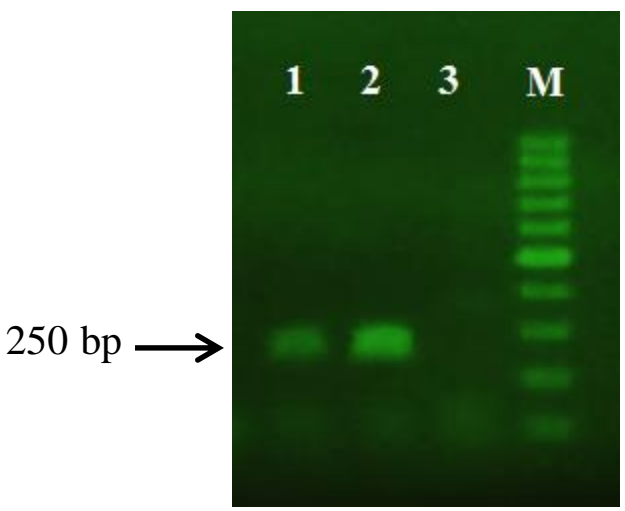

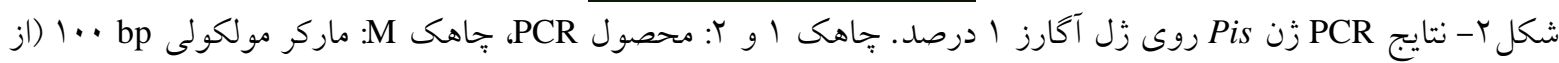

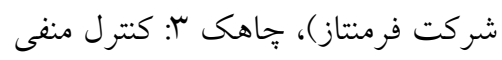

Figure 2. PCR results of Pis gene on 1\% agarose gel. 1 and 2: PCR product of Pis, M: 100bp Marker (Fermentas), 3: Negative control

همرديفسازى آن با توالىهاى بروتئينى مربوط به اين زن در ساير خياهان موجود در بايخـاه داده توسط نـرم افـزار

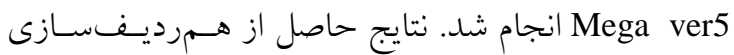

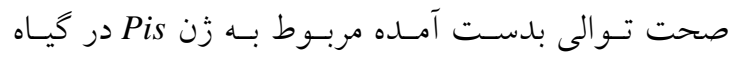

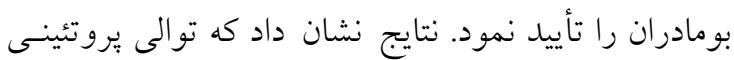
مربوط به زن Pis در كيا كياه Achillea millefolium

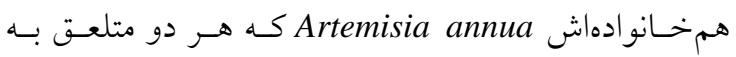
خانو اده Asteraceae هستند و با توالى هاى يروتئينى در دو Rosmarinus gavandula pedunculata officinalis

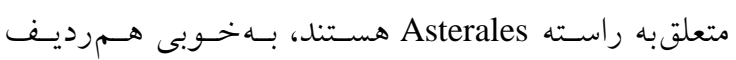
شدند. بررسى تنوع بين گونه ها و خانواده هاى مختلف گيـاهى

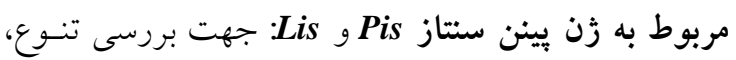

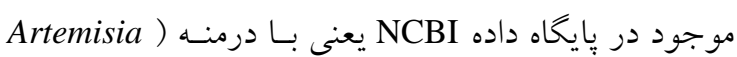

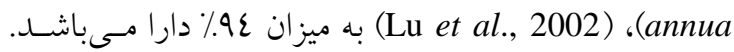
بنابر اين صحت توالى هاى به دست آمده از اين طريق تأييد كرديد. همجنـين تـوالى زن Pis جداسـازى شـــ از كيـاه بومادران در اين يزوهش با نتايج كزارش شده جداسـازى اين زن از ساير گياهان مانند مـريم كلسى ( Gambliel and (Croteau, 1982 ،راد (Bohlmann et al., 1997)، McKay et al., (Nieuwenhuizen et al., 2013) (Solanum habrochaites) 2003)، كوجن (203 (Gonzales-Vigil et al., 2012)

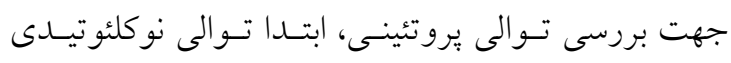

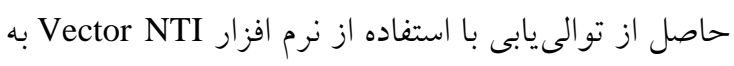

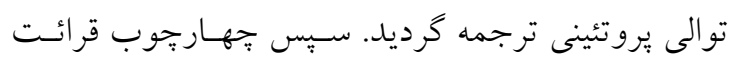

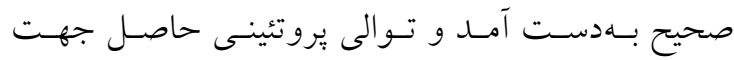


Lamiaceae بين خانواده Asteraceae با خانوادهى قرابت زنتيكى وجود دارد. در اين يزوهش نيز نتايج حاصل از رسم نمودار خوشهاى براى زن Pis خانواده

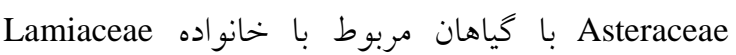
كمترين ميزان تنوع را نشان داده و در يك گروه قرار كرفتند كه با نتايج حاصل از طبقه بندى بر اساس زنهـاى كلرويلاستى توسـط برمر و همكاران، همسو مىباشد. تكثير زن لينالول سنتاز به روش واكنش زنجيرهاى يليمراز: بهمنظور سنتز DNA دورشتهاى و تكثير و

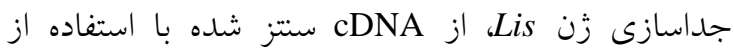
RNA F-LIN و و آنزيم R-LIN BioLabs در PCR استفاده گرديد. جهت تعيين دماى اتصال دقيق براى تكثير جفت آغازگر، از برنامه شيب دمايى استفاده شد. سيس، محصول PCR بر روى زل آكارز 1\% الكتروفورز گرديد. نتايج حاصل، تكثير قطعه

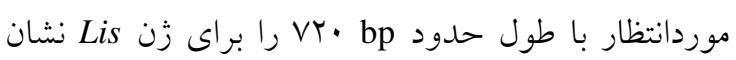
داد (شكل ع). دماى بهينه اتصال Co 00 تعيين شد. بررسى نتايج حاصل از توالى يابى زن لينالول سنتاز: نتايج حاصل از جستجوى شباهت توالى بهدستآمده در بومادران براى زن Lis نشان داد كه اين قطعه داراى شباهت بالايى با توالى زن Lis از گونههاى گياهى ديخر مىباشد. طبق نتايج حاصل از Blastn، اين توالى بيشتـرين شباهت را با توالى زن Lis مربوط به گونه ديخر خانواده گل ستاره اى ها (Asteraceae) موجود در يايخاه داده يعنى با درمنه Artemisia annua) بهميزان ع9 9 دارا مىباشد. بنابراين صحت توالى بدست آمده از اين طريق

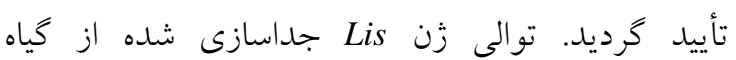
بومادران با نتايج گزارش شده جداسازى اين زن در ساير كياهان از جمله درمنه (Jia et al., 1999)، نعناع ( Mentha Iijima et (Crowell et al., 2002) (piperita ‘(Cseke et al., 1998) Clarkia concinna ،(al., 2004 سيـب (Nieuwenhuizen et al., 2013)، آرابيدويسيس و غيره مشابهت دارد. (Aubourg et al., 2002)
ميانخين Pairwise distance بر اساس دو مــل K2P و P P

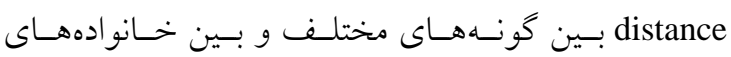
مختلف گૂاهى براى زن Pis محاسبه شد. همانطور كه در جدول r نشـان داده شـده اسـت، بـر اسـاس مــل كمتــرين تنــوع بــين Achillea millefolium و كيــاه هــــــانمانوادهاش Artemia annua و بيشــترين تنــوع

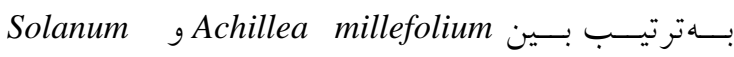
Abies grandis و بود. نتايج بهدسـتآمـده بر اساس مدل P-distance نيـز بــا نتـايج حاصـل از مــدل مطابقت داشت. در بررسى تنوع بـين خـانو اده هـاى K2P

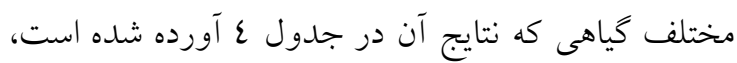
ميانخين كل تنوع براساس مدل K2P و مـدل P-distance براى كل خانوادههاى مـورد بررسسى بـه ترتيـب • TV/ • و .

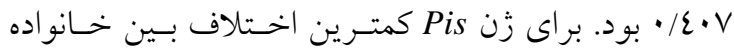
Asteraceae بـا خـانواده Lamiaceae مشــاهده كرديـــ و

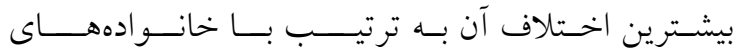
Pinaceae و SH Solanaceae بررسى روابط فيلوزنتيكى بر اساس زن يینن سنتاز: بهمنظور بررسى روابط فيلوزنتيكى براى زن Pis بين NCBI بومادران و ساير گياهان موجود در پايخاه داده درخت فيلوزنى بر يايه روش UPGMA با استفاده از نرم افزار Mega ver5 رسم گرديد (شكل س). همانطور كه در شكل مشخص است، گونههاى Achillea millefolium و Artemisia annua Asteraceae كمترين فاصله را با كونههاى Rosmarinus officinalis و متعلـت به Lavandula pedunculata Asterales داشته كه همخى متعلقبه راسته Lamiaceae مىباشند و بيشترين فاصله را با گياهان متعلق به خانواده دارند. اين نتايج با نتايج حاصل از تعيين تنوع با بإن Pinacea مقياس k2P همخوانى دارد. برمر و همكاران (Bremer et al., 2002) گزارش نمودند كه برطبق مطالعات فيلوزنى صورت گرفته بين خانوادههاى كياهى بر اساس شش زن كلرويلاستى (مانند rbcL و 


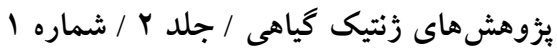

جدول ب- ميانكين Pairwise-distance بر اساس مدل K2P بين كونههاى مختلف گياهى مربوط به زن Pis

Table 3. Pairwise-distance average regarding K2P model among different plant species for Pis gene

$$
\text { كونه كياه }
$$

Plant species

$\begin{array}{llllllllllll}1 & 2 & 3 & 4 & 5 & 6 & 7 & 8 & 9 & 10\end{array}$

$\begin{array}{llllllllllll}0.066 & & & & & & & & \\ 0.815 & 0.837 & & & & & & & \\ 0.664 & 0.679 & 0.396 & & & & & & \\ 0.981 & 1.031 & 1.084 & 1.233 & & & & & & \\ 0.764 & 0.764 & 0.781 & 0.761 & 1.108 & & & & & \\ 0.879 & 0.902 & 0.808 & 0.710 & 1.173 & 0.146 & & & & \\ 0.835 & 0.815 & 0.779 & 0.695 & 1.029 & 0.124 & 0.131 & & & \\ 0.816 & 0.779 & 0.866 & 0.800 & 1.066 & 0.453 & 0.446 & 0.480 & & \\ 0.782 & 0.782 & 0.800 & 0.796 & 1.138 & 0.013 & 0.161 & 0.139 & 0.453 & \\ 0.834 & 0.815 & 0.778 & 0.727 & 1.080 & 0.101 & 0.116 & 0.026 & 0.491 & 0.116\end{array}$

جدول ع-ميانخين Pairwise-distance بر اساس مدل K2P بين خانوادههاى گياهى مربوط به زن Pis

Table 4. Pairwise-distance average regarding K2P model among plant families for Pis gene

\begin{tabular}{|c|c|c|c|c|c|}
\hline $\begin{array}{l}\text { خانو اده } \\
\text { Family }\end{array}$ & 1 & 2 & 3 & 4 & 5 \\
\hline 1. Asteraceae & & & & & \\
\hline 2. Lamiaceae & 0.749 & & & & \\
\hline 3. Solanaceae & 1.006 & 1.158 & & & \\
\hline 4. Pinaceae & 0.817 & 0.763 & 1.105 & & \\
\hline 5. Cupressaceae & 0.798 & 0.833 & 1.066 & 0.465 & \\
\hline
\end{tabular}

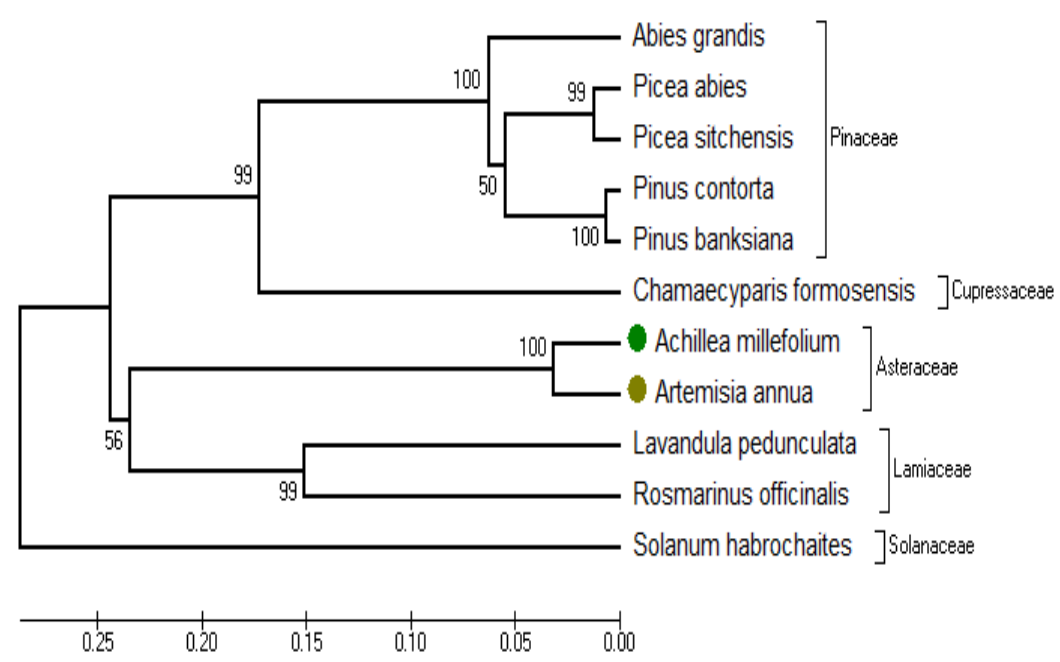

شكل r- درخت فيلوزنتيكى مربوط به روابط زنتيكى بومادران با ساير گياهان موجود در بايگاه NCBI بر اساس زن Pis با

UPGMA استفاده از روش

Figure 3. Phylogenetic tree for relationship of Achilleae Pis gene with other plants $P$ is sequences available in NCBI based on UPGMA method 


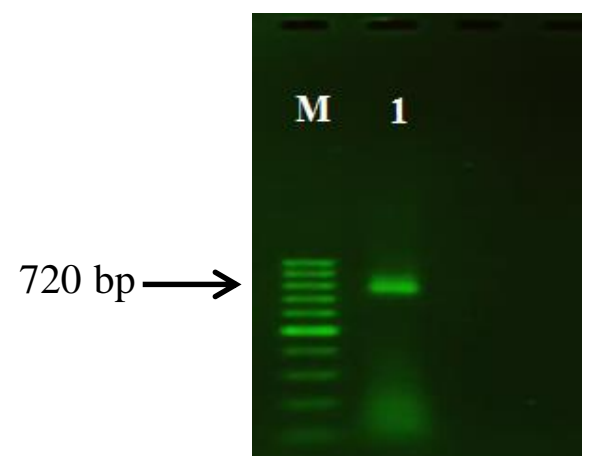

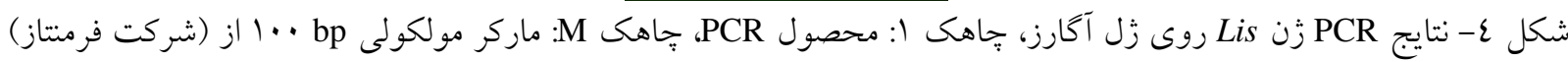
Figure 4. PCR results of Lis gene on agarose gel, 1: PCR product of Pis, M: 100bp Marker (Fermentas)

بهدستآمده بر اساس مدل P-distance با نتايج حاصل از

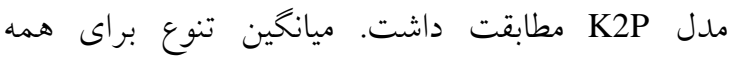
خانواده ها بر اساس مدل K2P و P-distance به ترتيب

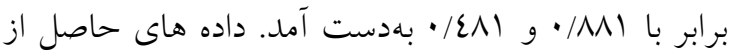
محاسبه ميانخين بر اساس مدل K2P بين خانوادههاى

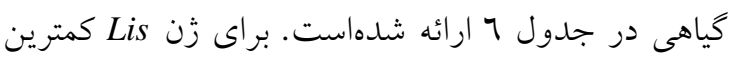

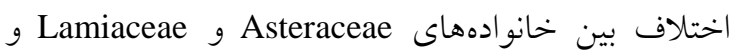
بيشترين اختلاف بهترتيب بين خانو ادههاى Asteraceae با

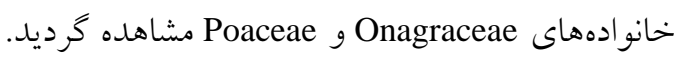
بررسى روابط فيلوزنتيكى بر اساس زن لينالول سنتاز: بهمنظور بررسى روابط فيلوزنتيكى براى زن Lis بين

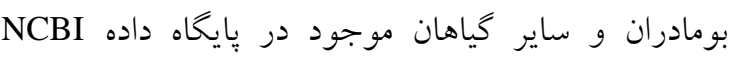
درخت فيلوزنى بر پايه روش UPGMA توسط نرم افزار Mega ver5 ترسيم شد (شكله). دندروكرام مربوطه نشان داد كه Achillea millefolium نزديكترين فاصله را

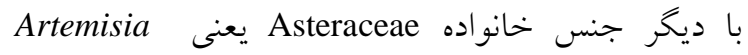
annиa Oriza Sativa Clarkia breweri K2P با نتايج بهدستآمده از محاسبه ميانگين بر بايه مدل

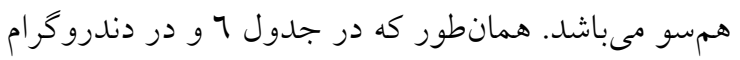

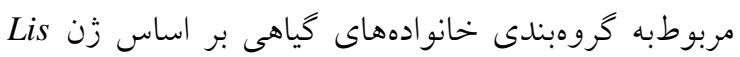
مشاهده مىشود، اختلاف تنوع كم بين خانوادهونهاى Asteraceae Asterales در رده Asterids مىباشد كه قرابت اين راستهها با استفاده
جهت بررسى توالى يروتئينى، توالى نوكلئوتيدى حاصل از

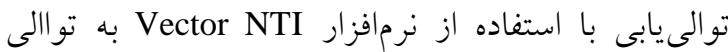
يروتئينى ترجمه شد. سبس جهارجوب قرائت صحيح

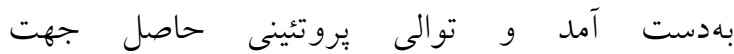

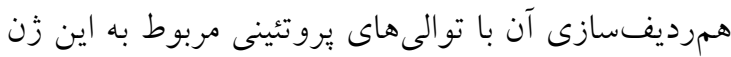

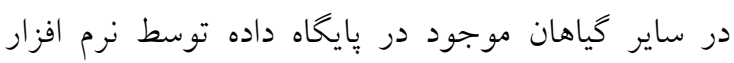
Mega ver5 صحت توالى بدست آمده مربوط به زن Lis در كياه

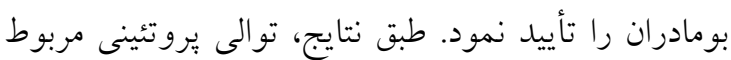

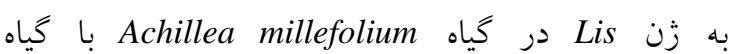
همخانوادهاش Artemisia апnиа كه هر دو متلعق به

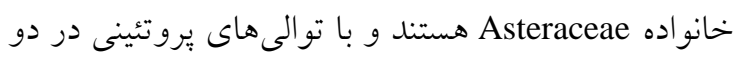
جنس Lavandula latifolia و كه متعلقبه خانواده Lamiaceae و همخى متعلقبه راسته Asterales بررسى تنوع بين جنسها و خانوادههاى مختلف گياهى مربوط به زن لينالول سنتاز: بهمنظور بررسى تنوع،

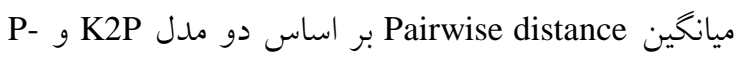
distance

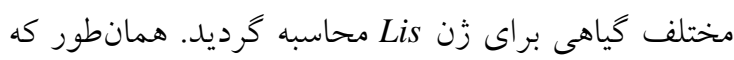
ع2P Kر جدول م نشان داده شده است، بر اساس مدل

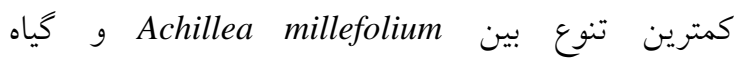
همخانوادهاش Artemisia аппиа و بيشترين تنوع Solanum بchillea millefolium باترتيب بين Abies grandis, habrochaites 
است (Ojimelukwe and Adler, 1999). بنابراين نتايج حاصل از اين بزوهش مىتواند جهت توليد تركيبات دارويسى و ايجاد و افزايش مقاومت به آفات و بيمارىها از طريق اسانس و توليد سوختهاى زيستى از طريق مهندسى متابوليك باكترى E.coli و مخمر ساكارومايسس لـ سرويزيه جهت توليد سوخت از بيشسازهاى ترينوئيدى بهدليل داشتن تركيبات احياشونده و سطح انرزى بالا استفاده شود. همجنين نتايج يزوهش حاضر مىتواند جهت مطالعات بيان زن، بررسىهاى فيلوزنتيك و استفاده از راهكارهاى مهندسى زنتيك جهت افزايش بيان زنهاى مذكور و توليد مواد مؤثره بيشتر و نيز تجارىسازى در صنايع مختلف مورد استفاده قرار كيرد.
از زن كلرويلاستى rbcL تأييد گرديده است ( Gustafsson Leite et al., 2007) (et al., 1996 (L) لايت و همكاران داشتند كه اوزنول (Eugenol) و آلفا و بتا- بينن داراى يتانسيل ضدميكروبى شديدى بوده و مىتوانند بهعنوان تركيبات ضدميكروبى در فورمولاسيونهاى دارويسى

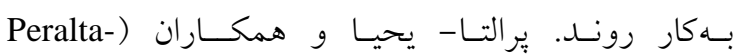
كزارش نمودند بينن و تعدادى (Yahya et al., 2012 ديخر از مونوترينهاى حلقوى مانند ليمونن، سابينن و تريينن به عنوان بيش سازهاى بالقوه سوخت هاى زيستى براى جت شناخته مىشونل. خاصيت حشرهكشى اسانس حاوى بينن و لينالول روى برخى آفات انبارى مانند شڤشه

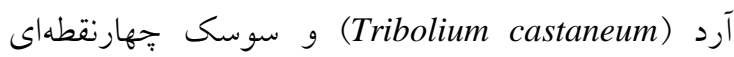
حبوبات (Callosobruchus maculatus) خزارش شده

جدول 0- محاسبه ميانخين Pairwise-distance بر اساس مدل K2P بين كونهاى مختلف گياهى مربوط به زن Lis Table 5. Pairwise-distance average regarding K2P model among different plant species for Lis gene

\begin{tabular}{|c|c|c|c|c|c|c|c|c|c|c|c|c|c|}
\hline & 1 & 2 & 3 & 4 & 5 & 6 & 7 & 8 & 9 & 10 & 11 & 12 & 13 \\
\hline \multicolumn{14}{|l|}{ 1. Achillea millefolium } \\
\hline 2. Artemisia annua & 0.059 & & & & & & & & & & & & \\
\hline 3. Cinnamomum camphora & 0.995 & 1.004 & & & & & & & & & & & \\
\hline 4. Cinnamomum osmophloum & 0.963 & 0.971 & 0.012 & & & & & & & & & & \\
\hline 5. Clarkia breweri & 1.188 & 1.210 & 1.127 & 1.167 & & & & & & & & & \\
\hline 6. Clarkia concinna & 1.210 & 1.233 & 1.127 & 1.167 & 0.016 & & & & & & & & \\
\hline 7. Lavandula angustifolia & 0.814 & 0.750 & 0.991 & 0.977 & 1.286 & 1.286 & & & & & & & \\
\hline 8. Lavandula latifolia & 0.795 & 0.762 & 0.855 & 0.855 & 1.254 & 1.254 & 0.410 & & & & & & \\
\hline 9. Malus domestica & 0.875 & 0.870 & 0.498 & 0.482 & 1.208 & 1.220 & 0.952 & 1.006 & & & & & \\
\hline 10. Mentha citrate & 0.905 & 0.866 & 1.048 & 1.033 & 1.360 & 1.355 & 0.264 & 0.410 & 0.913 & & & & \\
\hline 11. Oryza sativa & 1.003 & 1.077 & 0.537 & 0.538 & 1.562 & 1.526 & 1.054 & 1.082 & 0.631 & 0.994 & & & \\
\hline 12. Perilla citriodora & 0.822 & 0.776 & 0.936 & 0.937 & 1.369 & 1.365 & 0.269 & 0.349 & 0.824 & 0.258 & 0.995 & & \\
\hline 13. Perilla frutescena & 0.837 & 0.789 & 0.909 & 0.910 & 1.386 & 1.369 & 0.257 & 0.356 & 0.814 & 0.252 & 0.985 & 0.012 & \\
\hline 14. Rosa rugosa & 0.967 & 0.959 & 0.529 & 0.530 & 1.501 & 1.444 & 1.054 & 0.952 & 0.192 & 0.939 & 0.555 & 0.880 & 0.880 \\
\hline
\end{tabular}

جدول 7- محاسبه ميانخين Pairwise-distance بر اساس مدل K2P بين خانوادهاى گياهى مربوط به زن Lis

Table 6. Pairwise-distance average regarding K2P model among plant families for Lis gene

\begin{tabular}{|c|c|c|c|c|c|}
\hline $\begin{array}{l}\text { خانواده } \\
\text { Family }\end{array}$ & 1 & 2 & 3 & 4 & 5 \\
\hline teraceae & & & & & \\
\hline imiaceae & 0.983 & & & & \\
\hline nagraceae & 1.210 & 1.147 & & & \\
\hline imiaceae & 0.811 & 0.945 & 1.327 & & \\
\hline osaceae & 0.918 & 0.510 & 1.343 & 0.921 & \\
\hline paceae & 1.040 & 0.538 & 1.544 & 1.022 & 0.593 \\
\hline
\end{tabular}




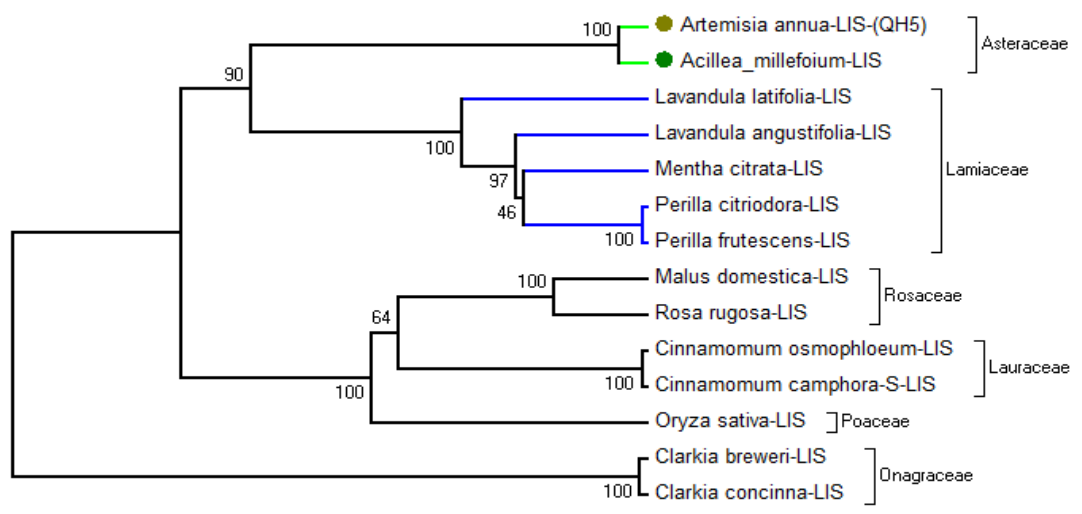

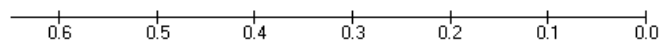

$$
\begin{aligned}
& \text { شكل 0- درخت فيلوزنتيكى مربوط به بومادران و ساير كياهان موجود در يايخاه NCBI بر اساس زن Lis با استفاده از روش } \\
& \text { UPGMA }
\end{aligned}
$$

Figure 5. Phylogenetic tree for relationship of Achilleae Lis gene with other plants Lis sequences available in NCBI based on UPGMA method

\section{References}

Aubourg, S., Lecharny, A. and Bohlmann, J. (2002). Genomic analysis of the terpenoid synthase (AtTPS) gene family of Arabidopsis thaliana. Molecular Genetics and Genomics, 267(6): 730-745.

Belletti, N., Ndagijimana, M., Sisto, C., Guerzoni, M.E., Lanciotti, R. and Gardini, F. (2004). Evaluation of the antimicrobial activity of citrus essence on Saccharomyces cerevisiae. Journal of Agricultural and Food Chemistry, 52: 6932-6938.

Bohlmann, J., Steele, C.L. and Croteau, R. (1997). Monoterpene synthases from grand fir (Abies grandis). cDNA isolation, characterization, and functional expression of myrcene synthase, (-)(4S)-limonene synthase, and (-)-(1S, 5S)-pinene synthase. Journal of Biological Chemistry, 272 (35): 21784-21792.

Bouwmeester, H.J., Kodde, J., Verstappen, F.W.A., Altug, I.G., de Kraker, J.W,. Wallaart, T.E. (2002). Isolation and characterization of two germacrene a synthase cDNA clones from chicory. Plant Physiology. 129, 134-144.

Bremer, B., Bremer, K., Heidari, N., Erixon, P., Olmstead, R.G., Anderberg, A.A. Källersjö, M. and Barkhordarian, E. (2002). Phylogenetics of asterids based on 3 coding and 3 non-coding chloroplast DNA markers and the utility of non-coding DNA at higher taxonomic levels. Molecular Phylogenetics and Evolution, 24(2): 274-301.

Buchbauer, G., Jirovetz, L., Jager, W., Dietrich, H. and Plank, C. (1991). Aromatherapy: evidence for sedative effects of the essential oil of lavender after inhalation. Z. Naturforsch, 46: 1067-1072.

Chalchat, J.C., Gorunovic, M.S., Petrovic, S.D. and Maksimovic, Z.A. (2001). Chemical composition of two wild species of the genus Salvia L. From Yugoslavia: Salvia aethiopis and Salvia verticillata. Journal of Essential Oil Research, 13(6): 416-418.

Chang, Y.J., Song, S.H., Park, S.H. and Kim, S.U. (2000). Amorpha-4, 11-diene synthase of Artemisia annua: cDNA isolation and bacterial expression of a terpene synthase involved in artemisinin biosynthesis. Archives of Biochemistry and Biophysics. 383(2): 178-184.

Cheng, A.X., Lou, Y.G., Mao, Y.B., Lu, S., Wang, L.J and Chen, X.Y. (2007). Plant terpenoids: biosynthesis and ecological functions, Journal of Integrative Plant Biology, 49(2): 179-186.

Christianson, D.W. (2006). Structural biology and chemistry of the terpenoid cyclases. Chemical Reviews, 106 (8): 3412-3442.

Crowell, A.L., Williams, D.C., Davis, E.M., Wildung, M.R. and Croteau, R. (2002). Molecular cloning and characterization of a new linalool synthase. Archives of Biochemistry and Biophysics, 405(1): 112-121.

Cseke, L., Dudareva, N. and Pichersky, E. (1998). Structure and evolution of linalool synthase. Molecular Biology and Evolution, 15(11): 1491-1498.

Gambliel, H. and Croteau, R. (1982). Biosynthesis of (+/-)-alpha-pinene and (-)-beta-pinene from geranyl pyrophosphate by a soluble enzyme system from sage (Salvia officinalis). The Journal of Biological Chemistry, 257(5): 2335-2342. 
Gonzales-Vigil, E., Hufnagel, D.E., Kim, J., Last, R.L. and Barry, C.S. (2012). Evolution of TPS20-related terpene synthases influences chemical diversity in the glandular trichomes of the wild tomato relative Solanum habrochaites. The Plant Journal, 71(6): 921-935.

Gustafsson, M.H., Backlund, A. and Bremer. B. (1996). Phylogeny of the Asterales sensu lato based on rbcL sequences with particular reference to the Goodeniaceae. Plant Systematics and Evolution, 199(3): 217-242.

Iijima, Y., Gang, D.R., Fridman, E., Lewinsohn, E. and Pichersky, E. (2004). Characterization of geraniol synthase from the peltate glands of sweet basil. Plant Physiology, 134(1): 370-379.

Jaimand, K. and Rezaee, M.B. (2004). Investigation on Chemical Constituents of Essential oils from Achillea mellifolium L. subsp. mellifolium by Distillation methods. Iranian Journal of Medicinal and Aromatic Plants Research, 20: 181-190 (In Persian).

Jennewein, S. and Croteau, R. (2001). Taxol: biosynthesis, molecular genetics and biotechnological applications, Applied Microbiology and Biotechnology, 57(1): 13-19.

Jia, J.W., Crock, J., Lu, S., Croteau, R. and Chen, X.Y. (1999). (3R)-Linalool synthase from Artemisia annua L.: cDNA isolation, characterization, and wound induction. Archives of Biochemistry and Biophysics, 372(1): 143-149.

Kim, M.Y., Chang, Y.J., Bang, M.H., Baek, N.I., Jin, J., Lee, C.H. and Kim, S.U. (2005). cDNA isolation and characterization of (+)-germacrene a synthase fromIxerls dentata form. Lbiflora Hara. Journal of Plant Biology, 48(2): 178-186.

Leite, A.M., Lim, E.D.O., Souza, E.L.D., Diniz, M.D.F.F.M., Trajano, V.N. and Medeiros, I.A.D. (2007). Inhibitory effect of beta-pinene, alpha-pinene and eugenol on the growth of potential infectious endocarditis causing Gram-positive bacteria. Brazilian Journal of Pharmaceutical Sciences, 43(1): 121-126.

Liu, Q., Manzano, D., Tanić, N., Pesic, M., Bankovic, J., Pateraki, I., Ricard, L., Ferrer, A., Vos, R., Krol, S. and Bouwmeester, H. (2014). Elucidation and in planta reconstitution of the parthenolide biosynthetic pathway. Metabolic Engineering, 23: 145-153.

Loizzo, M.R., Tundis, R. and Menechini, F. (2007). Cytotoxic activity of essential oils from labiatae and lauraceae families against in vitro human tumor models. Anticancer Research, 27: 3293-3300.

Lu, S., Xu, R., Jia, J.W., Pang, J., Matsuda, S.P. and Chen, X.Y. (2002). Cloning and functional characterization of a $\beta$-pinene synthase from Artemisia annua that shows a circadian pattern of expression. Plant Physiology, 130(1): 477-486.

McKay, S.A.B., Hunter, W.L., Godard, K.A., Wang, S.X., Martin, D.M., Bohlmann, J. and Plant, A.L. (2003). Insect attack and wounding induce traumatic resin duct development and gene expression of (-)-pinene synthase in Sitka spruce. Plant Physiology, 133(1): 368-378.

Mercier, C. and Chabardes, P. (1994). Organometallic chemistry in industrial vitamin A and vitamin E synthesis. Pure and Applied Chemistry, 66(7): 1509-1518.

Nieuwenhuizen, N.J., Green, S.A., Chen, X., Bailleul, E.J., Matich, A.J., Wang, M.Y. and Atkinson, R.G. (2013). Functional genomics reveals that a compact terpene synthase gene family can account for terpene volatile production in Apple. Plant Physiology, 161(2): 787-804.

Ojimelukwe, P.C. and Adler, C. (1999). Potential of zimtaldehyde, 4-allyl-anisol, linalool, terpineol and other phytochemicals for the control of confused flour beetle (Tribolium confusum J.D.V) (Col., Tenebrionidae). Journal of Pest Science, 72(4): 81-86.

Omidbeygi, R. (2007). Production and processing of medicinal plants. 2. Astane Qhodse Razavi Publications, Mashhad, Iran (In Persian).

Pattnaik, S., Subramanyam, V.R., Bapaji, M. and Kole, C.R. (1997). Antibacterial and antifungal activity of ten essential oils in vitro. Microbios Journal, 89(358): 39-46.

Peralta-Yahya, P.P., Zhang, F., Cardayre, S.B. and Keasling, J.D. (2012). Microbial engineering for the production of advanced biofuels. Nature, 488(7411): 320-328.

Pichersky, E. Raguso, R.A. Lewinsohn, E. and Croteau, R. (1994). Floral Scent Production in Clarkia (Onagraceae) (I. Localization and developmental modulation of monoterpene emission and linalool synthase activity). Plant Physiology, 106: 1533-1540.

Rispail, N., Nash, R. and Webb, K. (2005). Secondary metabolite profiling, Lopus japonicas handbook., Section 7, Springer, Dutch.

Rohloff, J., Skagen, E.B., Steen, A.H. and Iversen, T.H. (2000). Production of yarrow (Achillea millefolium L.) in Norway: essential oil content and quality. Journal of Agricultural and Food Chemistry, 48(12): 6205-6209.

Tajik, H. and Shokohi Sabet Jalali, F. (2009). Comparative evaluation of antimicrobial efficacy of aqueous and alcoholic extracts of yarrow against pathogenic microorganisms. Urmia Medical Journal, 19(4): 302-309 (In Persian). 


\title{
Isolation of Linalool Synthase and Pinene Synthase Genes from Yarrow (Achillea millefolium L.) Medicinal Plant
}

\section{Maryam Javedan Asl ${ }^{1}$, Hamid Rajabi Memari, ${ }^{2, *}$, Daryoosh Nabati Ahmadi ${ }^{2}$ and Afrasiyab Rahnama Ghahfarokhi ${ }^{2}$}

1- Former M.Sc. Student, Department of Agronomy and Plant Breeding, Faculty of Agriculture, Shahid Chamran University, Ahvaz, Iran

2- Assistant Professor, Department of Agronomy and Plant Breeding, Faculty of Agriculture, Shahid Chamran University, Ahvaz, Iran

(Received: October 05, 2014 - Accepted: March 18, 2015)

\begin{abstract}
Yarrow (Achillea millefolium) is an herbaceous and perennial plant species which belongs to the Asteraceae family. Yarrow's essential oil has different compounds of monoterpene and sesquiterpens, which its main constituents are pinene and linalool. These compunds have anti-microbial and anti-pest activities and also can be used in the food industry, perfumery and cosmetics. The aim of the present study was to use the degenerate primers approach in order to isolate Pinene synthase and linalool synthase genes from Yarrow plant. Up to date, there is no any report on the availability of these genes in the world gene bank. In this investigation the total RNA was extracted from Yarrow then pinene synthase and linalool synthase genes were isolated, using degenerate primers and Polymerase Chain Reaction (PCR). PCR amplified two bands of $250 \mathrm{bp}$ and $720 \mathrm{bp}$. The sequence data were compared with NCBI gene bank data. The results of diversity study among varieties and families based on Pis and Lis genes showed most similarity between Achillea and Artemisia plants. Also this similarity was seen between Asteraceae and Lamiaceae families and these families grouped together same group. These results also showed a relatively high similarity of Pis and Lis with some other plants which confirmed sequencing data.
\end{abstract}

Keywords: Degenerate primer, Achillea millefolium, Pinene synthase, Terpenes, Linalool synthase

\footnotetext{
* Corresponding Author, E-mail: memari@scu.ac.ir
} 